\title{
Nilai Limfosit dan Monosit Sapi Bali yang Dipelihara Berbasis Organik
}

\section{(VALUE OF LIMFOSIT AND MONOSIT OF BALI CATTLE BASED ON ORGANIC MAINTAIN)}

\section{Putu Indra Parmayoga ${ }^{1 *}$, Ni Ketut Suwiti ${ }^{1}$, I Nyoman Suartha ${ }^{2}$, I Gusti Ayu Agung Suartini ${ }^{3}$}

\author{
${ }^{1}$ Laboratorium Histologi Veteriner, Fakultas Kedokteran Hewan, Universitas Udayana. \\ ${ }^{2}$ Departemen Klinik Veteriner, Fakultas Kedokteran Hewan Universitas Udayana. \\ 3Laboratorium Biokimia Veteriner Fakultas Kedokteran Hewan Universitas Udayana. J1. PB. \\ Sudirman, Denpasar Bali.*Email: indraparmayoga7@gmail.com
}

\begin{abstract}
ABSTRAK
Sapi bali dipelihara dengan berbagai cara yakni sistem intensif, semi intensif (simantri), konvensional dan pemeliharaan berbasis organik. Berbasis organik artinya sapi bali diberikan pakan yang berasal dari lingkungannya tanpa tambahan zat kimia seperti mineral, vitamin, obat-obatan, vaksin, suplemen, dan zat adiktif lainnya. Penelitian ini bertujuan untuk melihat nilai limfosit dan monosit sapi bali yang dipelihara berbasis organik. Sampel berupa whole blood diambil melalui vena jugularis dan dilakukan pemeriksaan hematologi menggunakan alat Veterinary Hematology Analyzer. Hasil penelitian menghasilkan rerata total limfosit dan monosit $3,77 \times 10^{3} / \mu 1$ dan $0,53 \times 10^{3} / \mu 1$. Rerata nilai limfosit dan monosit sapi bali yang dipelihara berbasis organik masih berada pada rentang nilai normal.
\end{abstract}

Kata kunci: Sapi bali; pakan organic; limfosit; monosit; hematologi.

\section{ABSTRACT}

Bali cattle are maintained in various ways, namely intensive, semi-intensive (simantri) systems, conventional and organic based maintenance. Organic based means that Bali cattle are fed with food from their environment without chemical additives such as minerals, vitamins, medicines, vaccines, supplements, and other addictive substances. This study aims to look at the value of Bali cattle lymphocytes and monocytes that are maintained on an organic basis. Samples in the form of whole blood were taken through the jugular vein and hematological examination was performed using the Veterinary Hematology Analyzer. The results of the study produced a mean total lymphocytes and monocytes $3,77 \times 10^{3} / \mu 1$ dan 0,53 $\mathrm{x} 10^{3} / \mu 1$. The average value of bali lymphocytes and monocytes that are maintained on an organic basis are still in the range of normal values.

Keywords: Bali cattle; organic feed; lymphocytes; monocytes; hematology.

\section{PENDAHULUAN}

Sapi bali merupakan sapi murni asal Indonesia yang tersebar luas diseluruh wilayah Indonesia. Sapi bali merupakan hasil domestikasi dari banteng (Bibos Banteng) (Nugraha et al., 2016). Sapi bali merupakan hewan ruminansia yang mempunyai ciri khas tersendiri. Banyak keunggulan dari sapi bali yaitu prosentase karkas yang cukup besar yaitu 53,26\% dan mempunyai daya cerna yang baik terhadap pakan serta daya adaptasi yang baik terhadap lingkungan (Besung et al., 2019; laksmi et al., 2019). Adapun kekurangan yang dimiliki sapi bali adalah pertumbuhan yang lambat, tingkat kematian pedet tinggi dan rentan terhadap beberapa penyakit tertentu seperti penyakit jembrana, bali ziekte dan malignant catarrhal fever (Kusumaningsih, 2002).

Di Provinsi Bali beternak sapi bali sudah menjadi mata pencaharian yang sangat banyak dilakukan oleh penduduk. Sebagian besar sudah memelihara dengan 
sistem Simantri (Sistem Pertanian Terintegrasi) yang diprogramkan Pemerintah Provinsi Bali (Suputra et al., 2019; Parwata et al., 2019). Di Desa Bulian, Kecamatan Kubutambahan, Kabupaten Buleleng, di samping memelihara dengan sistem simantri, sapi bali juga dipelihara dengan sumber pakan berbasis organik. Sumber pakan diperoleh dari lingkungan yang dipastikan bebas dari zat kimia (pestisida).

Pakan merupakan bagian yang sangat penting dari usaha peternakan. Pakan dapat berpengaruh terhadap pertambahan bobot hidup ternak. Peternakan berbasis organik menggunakan pakan hijauan yang berada disekitar peternakan yang pemeliharaan tanpa zat kimia maupun desinfektan. Air yang diberikan pada peternakan di Desa Bulian tersebut adalah air murni tanpa tambahan zat atau bahan kima seperti mineral, vitamin, obat-obatan, vaksin dan suplemen.

Pemberian pakan organik dari limbah hasil pertanian yang dimana dedak padi, rumput buangan dan lainnya, diharapkan dapat meningkatkan nilai jual dari ternak sapi bali. Sapi bali yang diberikan pakan organik tanpa adanya zat kimia dimungkinkan mempunyai sistem kekebalan imun yang berbeda dengan sapi bali yang dipelihara dengan cara lainnya, beradaptasi terhadap lingkungan, mempunyai resistensi tinggi terhadap kutu dan penyakit, dan mungkin kemampuan metabolisme sapi bali yang diberikan pakan organik lebih tahan dari serangan penyakit. Salah satu indikator yang dapat dijadikan penanda adalah dengan mengukur nilai hematologi. Oleh karena itu perlu dilakukan penelitian untuk melakukan pemeriksaan hematologi sel darah putih khususnya limfosit dan monosit.

\section{METODE PENELITIAN}

Sebanyak 10 sapi bali yang diambil sampel darahnya (whole blood) dari vena yugularis dari sapi bali peternakan Bapak I Wayan Kantra Desa Bulian, Kecamatan Kubutambahan, Kabupaten Buleleng.
Sistem pemeliharaan yang digunakan adalah pemeliharaan secara organik. Data yang diambil adalah hasil nilai hematologi darah sapi bali yaitu monosit dan limfosit dengan pemeriksaan menggunakan veterinary hematology analyzer. Pengambilan sampel dilakukan dengan cara sapi direstrain agar tidak melawan saat dilakukan pengambilan darah. Tampon yang berisikan alkohol diusapkan ke leher sapi kemudian darah diambil melalui vena jugularis dengan menggunakan spuit yang ditampung dengan tube yang berisikan antikoagulan. Diberikan kode 1 sampai 10 pada tabung dan dimasukan ke dalam cool box yang sudah berisiksan es batu. Pemeriksaan hematologi darah akan menggunakan veterinary hematology analyzer, dengan cara: alat veterinary hematology analyzer dinyalakan kemudian background terlebih dahulu, ini berfungsi untuk menetralkan agar data yang akan kita dapat lebih akurat. Sampel dihomogenkan selama \pm 5 menit dengan roller mixer. Klik Ikon New Sampel, kemudian klik next sampel, kemudian masukkan identitas yang meliputi data sampel dan nama hewan yang akan diperiksa darahnya (sapi), klik tombol OK. Tutup tabung sampel dibuka dan kemudian tabung diletakkan dibawah kapiler sampel (sampling nozzle) sampai ujung kapiler menyentuh dasar tabung. Tombol counting ditekan, sehingga kapiler sampel akan menyedot sampel sampai kapiler sampel akan tertarik kedalam instrument dan sampel secara otomatis akan diproses oleh alat ini. Hasil pemeriksaan darah lengkap dianalisis oleh alat tersebut dan hasilnya tercetak secara langsung (Rumlaklak dan Toelle, 2015). Data berupa nilai hematologi dianalisis dengan deskriptif kuantitatif dan juga menggunakan analisis statistika dasar.

\section{HASIL DAN PEMBHASAN}

Hasil dari pemeriksaan limfosit dan monosit sapi bali yang dipelihara berbasis organik yang terdapat di Peternakan Bapak I Wayan Kantra Desa Bulian, Kecamatan Kubutambahan, Kabupaten Buleleng 
dengan menggunakan alat veterinary hematology analyzer dapat dilihat pada Tabel 1 dan Tabel 2.

Table 1. Nilai Limfosit dan Monosit Sapi

Bali yang Dipelihara Berbasis Organik

\begin{tabular}{lll}
\hline Sampel & $\begin{array}{l}\text { Limfosit } \\
\left(x_{10}^{3} / \mu 1\right)\end{array}$ & $\begin{array}{l}\text { Monosit } \\
\left(\text { x 10 }^{3} / \mu 1\right)\end{array}$ \\
\hline Sp 1 & 2,7 & 0,4 \\
Sp 2 & 5,3 & 0,6 \\
Sp 3 & 4,2 & 0,6 \\
Sp 4 & 5,0 & 0,4 \\
Sp 5 & 5,8 & 0,9 \\
Sp 6 & 3,0 & 0,5 \\
Sp 7 & 3,8 & 0,4 \\
Sp 8 & 3,7 & 0,6 \\
Sp 9 & 1,5 & 0,5 \\
Sp 10 & 2,7 & 0,4 \\
\hline Total & 37,7 & 5,3 \\
\hline Rerata & 3,77 & 0,53 \\
\hline St. Dev & 1,3417 & 0,1567 \\
\hline Keterangan & Sp
\end{tabular}

Keterangan: $\mathrm{Sp}=$ sampel
Tabel 1. menujukkan rerata nilai limfosit sapi bali yang dipelihara berbasis organik sudah menunjukkan nilai limfosit normal yakni $3,77 \times 10^{3} / \mu 1 \pm 1,3417$ Dari seluruh sampel didapatkan nilai tetinggi yakni $5,8 \times 10^{3} / \mu 1$ dan nilai terendah yakni $1,5 \times 10^{3} / \mu \mathrm{l}$. Tabel 1 . juga menujukkan rerata nilai monosit sapi bali yang dipelihara berbasis organik yakni $0,53 \mathrm{x}$ $10^{3} / \mu 1 \pm 0,1567$. Nilai monosit tetinggi yakni $0,9 \times 10^{3} / \mu$ l dan terendah yakni $0,4 \mathrm{x}$ $10^{3} / \mu \mathrm{l} . \quad 40 \%$ dari seluruh sampel menunjukkan nilai terendah pada pemeriksaan monosit sapi bali yang dipelihara berbasis organik.

Pada Gambar 1 dapat dilihat bahwa nilai limfosit dan monosit sapi bali yang dipelihara berbasis organik sangat bervariasi. Nilai limfosit dan monosit pada sampel no 5 memilki nilai tertinggi.

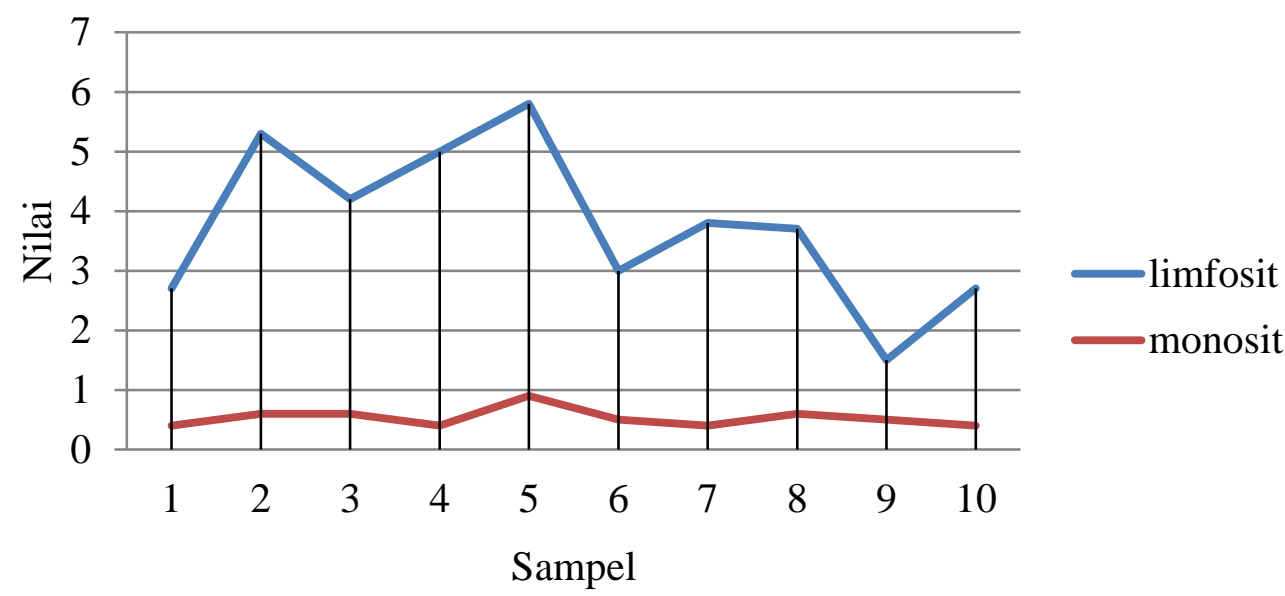

Gambar 1. Nilai Limfosit dan Monosit Sapi Bali

Limfosit dan monosit memiliki peranan yang penting dalam mempertahankan kondisi tubuh dari benda asing. Jumlah limfosit dan monosit pada umumnya meningkat jika tubuh terinfeksi oleh mikroorganisme dari luar tubuh. Total dan tipe sel darah putih dapat digunakan untuk mendiagnosis status infeksi pada ternak (Fassah dan Khotijah, 2016). Dari hasil yang didapat nilai rerata dari pemeriksaan limfosit yakni $3,77 \times 10^{3} / \mu 1 \pm 1,3417$ dan nilai rerata dari pemeriksaan monosit yakni
$0,53 \times 10^{3} / \mu 1 \pm 0,1567$ nilai tersebut masih pada batas normal. Untuk nilai limfosit pada sapi bali yang tidak dipelihara berbasis organik pada umumnya adalah $1,8-8,1 \times 10^{3} / \mu 1$ dan nilai monositnya yakni $0,1-0,7 \times 10^{3} / \mu 1$ (Pawitri et al., 2014). Dalam hal ini status kesehatan dapat dilihat dari nilai rerata limfosit dan monosit pada tubuh hewan.

Peranan limfosit yaitu mempertahankan kondisi tubuh dari serangan benda asing dan melindungi tubuh dari infeksi, baik 
yang disebakan oleh virus, atau bakteri, dan berperan menghancurkan sel kanker, serta sebagai pembentukan antibodi. Peranan monosit yaitu sebagai sel pertahanan awal spesifik pada hewan untuk menyingkirkan benda asing yang masuk ke dalam tubuh (Fahrimal et al., 2014), memfagositosis, dan menghancurkan benda-benda asing atau jaringan yang mati dengan memanfaatkan partikel-partikel asing untuk meningkatkan kekebalan tubuh, seperti makrofag dalam merespon antigen (Aiba $e t$ al., 2016).

Pada hasil pemeriksaan limfosit (Tabel 1) sampel no 9 nilai limfosit menurun dan pada hasil pemeriksaan monosit (Tabel 2) sampel no 5 mengalami kenaikan nilai monosit. Hal ini dipengaruhi oleh kondisi hewan. Kondisi hewan merupakan faktor lain yang berpengaruh pada nilai limfosit dan monosit dalam tubuh hewan. Pada saat pengambilan sampel, salah satu sapi bali sangat susah di-handle, ini menyebabkan kondisi stres pada sapi bali tersebut. Kondisi stres sering mempengaruhi nilai limfosit dan monosit adalah stress (Kannan et al., 2000). Stres merupakan perubahan kondisi tubuh sebagai respons terhadap suatu ancaman tertentu sehingga tubuh melakukan penyesuaian terhadap kondisi tersebut. Stres pada hewan dapat diukur melalui rasio limfosit dan monosit (Suprayogi et al., 2017). Menurut Kannan et al. (2000), ternak yang stres dapat mengalami peningkatan jumlah neutrofil dan penurunan jumlah limfosit. Hal ini disebabkan oleh respons kortisol di dalam darah. Kondisi stres ini terkait juga dengan seberapa sering hewan tersebut di-handle. Hewan yang sering di-handle secara berkala akan mengurangi stres sehingga tidak terjadi banyak perubahan parameter hematologi (Tjendradjaja, 2011).

Sumber pakan sangat berpengaruh, jika pakan yang diberikan sudah sesuai gizi yang tepat maka nilai limfosit dan monosit pasti akan normal. Pakan merupakan hal utama dalam tata laksana pemeliharaan, apabila kebutuhan pakan tidak terpenuhi maka akan berdampak pada status gizi ternak. Ketersediaan hijauan pakan ternak di Indonesia berfluktuasi tergantung pada musim, dimana pada musim penghujan produksi hijauan melimpah sedangkan pada musim kemarau akan kekurangan hijauan pakan. Selain itu pemanfaatan rumput sebagai pakan ruminansia kurang memenuhi kebutuhan nutrisi ternak, terutama kebutuhan nutrisi mineral. Sebagai akibatnya aktivitas rumen kurang optimum (Supriyati et al., 2000).

Suplemen, mineral, dan vitamin sebenarnya dibutuhkan dalam campuran pakan ternak karena dapat membantu meningkatkan kesehatan tubuh hewan. Pada penelitian ini, pakan yang digunakan adalah pakan organik tanpa adanya tambahan suplemen, vitamin, mineral, dan zat lainnya. Nilai rerata limfosit sapi bali yang dipelihara berbasis organik lebih rendah dari pada nilai rerata normal sapi bali pada umumnya. Nilai rerata monosit sapi bali yang dipelihara berbasis organik lebih tinggi dari pada nilai rerata sapi bali pada umumnya, tapi nilai rerata limfosit dan monosit masih dalam batas normal. Hal tersebut sangat dipengaruhi oleh pakan organik. Penambahan suplemen, vitamin dan mineral pada pakan seharusnya sangat diperlukan oleh tubuh hewan. Seperti yang ditulis oleh Fassah (2016) suplementasi vitamin-E menghasilkan perbedaan yang siginifikan pada indeks aktivitas fagositosis leukosit dan neutrofil. Vitamin-E berperan penting dalam melindungi membran sel dan komponen sel imun lain dari peroksidasi lipid, sehingga aktivitas fagositosisnya meningkat. Suplementasi vitamin-E sebagai antioksidan mampu melindungi integritas fosfolipid dalam membrane sel dari reaksi oksidatif. Hal tersebut memengaruhi fungsi sel-sel imun terutama sel-T dalam berinteraksi dengan senyawa patogen, selain itu vitamin-E juga meningkatkan proliferasi sel-T (Siswanto et $a l ., 2013)$. Hal ini pula yang menyebabkan keberadaan senyawa patogen tidak meningkat, sehingga jumlah leukosit dalam darah relatif stabil sama halnya dengan nilai rerata sapi bali yang dipelihara secara 
organik memiliki nilai rerata limfosit pada batas normal.

Selain suplemen vitamin E, mineral juga sangat berperan dalam kestabilan leukosit terutama limfosit dan monosit. Mineral Zn sangat berberan dalam sistem imunitas. Setiap sel membutuhkan mineral $\mathrm{Zn}$ agar tetap hidup sehat dan dapat berfungsi dengan baik. Pada ternak dewasa, kandungan total $\mathrm{Zn}$ dalam komponen darah terdistribusi seperti berikut pada eritrosit $75 \%$, plasma $22 \%$, dan leukosit 3\%. Zn dalam eritrosit, hampir semuanya secara eksklusif sebagai komponen enzim karbonik anhydrase (Widhyari, 2014). Peningkatan jumlah limfosit dapat dilihat pada sampel no 5, hal ini disebabkan oleh faktor individu seperti stres, faktor stres berpengaruh terhadap peningkatan nilai limfosit dan monosit. Mineral Zn mampu meningkatkan produksi limfokin menyebabkan sel limfosit mampu berdiferensiasi dan berproliferasi. Defisiensi $\mathrm{Zn}$ dapat menyebabkan penurunan jumlah limfosit (limfopenia). Blastogénesis limfosit secara nyata menurun pada hewan yang mengalami stress. Defisiensi $\mathrm{Zn}$ dikaitkan dengan perubahan fungsi sistem imun, seperti menurunnya fungsi sel $\mathrm{B}$ dan $\mathrm{T}$, reaksi hipesensitivitas, fagositosis, dan produksi sitokin. Penambahan $\mathrm{Zn}$ mampu meningkatkan produksi sitokin oleh sel limfosit $\mathrm{T}$ helper sehingga menyebabkan terjadinya proliferasi dan diferensiasi sel (Widhyari, 2014). Hal ini mengindikasikan suplementasi $\mathrm{Zn}$ diduga mampu menekan respons stress yang mungkin terjadi (Widhyari et al., 2011).

Limfosit diperoleh dari mineral $\mathrm{Fe}$, berarti sapi bali yang dipelihara berbasis organik ketersediaan Fe yang ada dalam tubuh mampu mengatasi kebutuhan yang diperlukan. Mineral $\mathrm{Fe}$ menyebabkan intensitas aktivitas leukosit meningkat jika terjadi infeksi, karena ferritin selain terhapat pada sel darah merah juga terdapat pada sel darah putih. Manfaat kandungan zat besi dalam tubuh sebagain komponen sangat penting dalam fungsi sistem imunitas dan meningkatkan sistem pertahanan tubuh (Setiawati, 2007). Fase proliferasi dan aktivasi limfosit membutuhkan $\mathrm{Fe}$, jika hewan mengalami defisiensi Fe maka sistem imunitasnya akan terganggu. Selain limfosit, Fe juga terdapat pada monosit, monosit adalah sel darah putih yang memfagositosis partikel lebih besar (makrofag) dan akan diproduksi lebih banyak jika agen penyakit masuk dalam tubuh hewan. Beberapa penelitian menyebutkan adanya interaksi kebutuhan zat besi dalam pakan dengan respon imunitas dan perlawanan terhadap adanya agen penyakit (Setiawati et al., 2007).

Rendahnya nilai rerata limfosit dan monosit dapat disebabkan kurangnya asupan nutrisi khususnya mineral. Mineral merupakan syarat yang ada di dalam pakan dan juga sangat berperan dalam sistem pertahanan tubuh. Salah satunya yaitu tembaga $(\mathrm{Cu})$. Mineral $\mathrm{Cu}$ sangat berperan dalam sistem imun yang dibuktikan dengan metabolisme tembaga mempengaruhi pembentukan antibodi dan berperan dalam sistem enzimatis untuk mengeliminasi racun radikal bebas (Aloha et al., 2010). Arthington (2006) mengatakan enzim yang dibentuk oleh $\mathrm{Cu}$ adalah tembaga/seng superoxide dismutase dan ceruloplasmin. Enzim tersebut memiliki peranan dalam sistem imun. Pada sapi defisiensi $\mathrm{Cu}$ dapat mengakibatkan neutropenia serta sistem inflamasi terganggu. Defisiensi mineral $\mathrm{Cu}$ dapat menurunkan jumlah limfosit perifer. (Putra et al., 2016).

Keterkaitan pakan dengan suplemen, vitamin, dan mineral sangat berpengaruh dalam sistem pertahanan tubuh hewan. Pada penelitian pemeliharaan sapi bali secara organik sudah mencakupi seluruh asupan gizi dengan adanya hasil nilai limfosit dan monosit dalam batas normal.

\section{SIMPULAN DAN SARAN}

\section{Simpulan}

Nilai limfosit dan monosit darah sapi bali yang dipelihara berbasis organik adalah $3,77 \times 10^{3} / \mu \mathrm{l}$ dan $0,53 \times 10^{3} / \mu 1$ 
masih dan berada pada batas normal nilai limfosit dan monosit sapi.

Saran

Sitem pemeliharaan berbasis organik dapat diterapkan pada peternakan sapi bali. Sistem pemeliharaan berbasis organik ini dapat dijadikan referensi kepada pemerintah dan peternak untuk pengembangan Bali Beef Organik.

\section{DAFTAR PUSTAKA}

Aiba, Sumiaty, W. Manalu, A. Suprayogi dan Maheshwari H. 2016. Gambaran nilai hematologi tikus putih betina dara pada pemberian tombong kelapa. Acta. Veterinaria Indonesiana. 4(2): 74-81.

Ahola JK, Engle TE, Whittier JC. 2010. Trace minerals and the immune system in cattle. Western Beef Resource Committee. 315: 1-5.

Arthington JD. 2006. Trace mineral nutrition and immune competence in cattle. Florida Ruminant Nutrition Symposium, Best Western Gateway Grand, Gainesville FL. February 1-2, 2006.

Besung INK, Watiniasih NL, Mahardika IGNK, Agustina KK, Suwiti NK. 2019. Mineral levels of Bali cattle (Bos javanicus) from different types of land in Bali, Nusa Penida, and Sumbawa Islands (Indonesia). Biodiversitas. 20(10): 2931-2936.

Fahrimal, Yudha., Eliawardani, A. Rafina, A. Azhar dan N. Asmilia. 2014. Profil darah tikus putih (rattus norvegicus) yang diinfeksikan trypanosoma evansi dan diberikan ekstrak kulit batang jaloh (salix tetrasperma roxb). J. Kedokteran Hewan. 8(2): 164-168

Fassah MD. Khotijah L. 2016. Pengimbuhan Vitamin-E dalam ransumkaya asam lemak tidak jenuhterhadap profil darah induk domba laktasi. J. Vet. 17(3): 430-439.

Nugraha HY, Sampurna IP, Suatha IK. 2016. Pengaruh pemberian pakan tambahan pada induk sapi bali terhadap ukuran dimensi panjang pedet. Buletin Veteriner Udayana. 8(2): 159-165.
Pawitri SPLN, Dwinata IM, Dharmawan NS. 2014. Total dan diferensial leukosit sapi bali yang terinfeksi cysticercus bovis secara eksperimental. Indonesia Medicus Veterinus. 3(3): 213-222.

Kannan G, Terrill TH, Kouakou B, Gazal OS, Gelaye S. 2000. Transportation ofgoats: effects on physiological stress responses and live weight loss. J. Anim. Sci. 78(6): 1450-1457.

Kusumaningsih A. 2002. The use of bali breed. Makalah Falsafah Science, Pragram Sarjana, Institut Pertanian Bogor, Bogor.

Laksmi DNDI, Trilaksana IGNB, Darmanta RJ, Darwan M, Bebas IW, Agustina KK. 2019. Correlation between body condition score and hormone level of Bali cattle with postpartum anestrus. Indian J. Anim. Res. 53(12): 1599-1603.

Parwata DMD, Sampurna IP, Sukada IM, Agustina KK. 2019. Klasterisasi manajemen pengolahan limbah sapi bali pada simantri di kabupaten Badung. Buletin Veteriner Udayana. 11(1): 51-57.

Putra IPC, Suwiti NK, Ardana IBK. 2016. Suplementasi mineral pada pakan sapi bali terhadap diferensial leukosit di empat tipe lahan. Buletin Veteriner Udayana. 8(1): 8-16.

Rumlaklak YY, Toelle NN. 2015. Gambaran hematologi pada rusa timor (Cervus timorensis). J. Kajian Vet. 3(1): 77-82.

Setiawati MA, Nuryati S, Mokoginta I, Suprayudi MA, W. Manelu W. 2007. Pengaruh suplementasi fe-anorganik terhadap gambaran sel darah kerapu cromileptes altivelis terinfeksi bakteri vibrio parahaemolyticus. J. Biologi Indonesia. 4(4): 203-215.

Siswanto. 2011. Gambaran sel darah merah sapi bali (studi rumah potong). Buletin Veteriner Udayana. 3(2): 99-103

Siswanto, Budisetyawati, Ernawati F. 2013. Peran beberapa zat gizi mikro dalam sistem imunitas. Gizi Indonesia. 36: 5764. 
Suprayogi A, Alaydrussani G, Ruhyana AY. 2017. Nilai hematologi, denyut jantung, frekuensi respirasi, dan suhu tubuh ternak sapi perah laktasi di Pangalengan. J. Ilmu Pertanian Indonesia. 22(2): 127-132.

Supriyati D. 2000. Pengaruh suplementasi $\mathrm{Zn}, \mathrm{Cu}$ Dan Mo anorganik dan organik terhadap kecernaan rumput secara in vitro. JITV. 5(1): 276-278.

Suputra GWK, Sampurna IP, Nindhia TS, Agustina KK. 2019. Klasterisasi manajemen perkandangan sapi bali pada simantri di kabupaten badung Bali. Buletin Veteriner Udayana. 11(2): 128-135.

Tjendradjaja TM. 2011. Leukosit sebagai salah satu parameter kesehatan rusa timor (Cervus timorensis) di usaha penangkaran rusa timor Kecamatan Dawe Kabupaten Kudus. Institut Pertanian Bogor. Bogor.

Widhyari SD, Esfandiari A, Wijaya A, Wulansari R, Widodo S, Maylina L. 2014. Efek penambahan mineral zn terhadap gambaran hematologi pada anak sapi frisian holstein. J. Ilmu Pertanian Indonesia. 19(3): 150-155.

Widhyari SD, Widodo S, Wibawan IWT, Sutama IK, Esfandiari A. 2011. Profil kadar kortisol dan seng pada kambing peranakan etawah saat melahirkan yang diberi tambahan seng dalam pakannya. J. Vet. 12(3): 220-228. 